\title{
36. The UN Watercourses Convention and its complementary User's Guide: Indispensable ingredients for global water cooperation
}

\author{
Ariel Litke \\ Institut d'Etudes Politiques de Paris, France \\ Alistair Rieu-Clarke \\ University of Dundee, United Kingdom
}

International water law (IWL) has developed mainly over the second half of the twentieth century, and has enjoyed increasing legitimacy in recent times (McCaffrey 2013). A range of legal instruments have progressively strengthened key principles of international water law and defined the rights and duties of states with respect to their uses of shared watercourses, ${ }^{1}$ such as: the International Law Association's 1966 Helsinki Rules (ILA 1967), the United Nations Economic Commission for Europe 1992 Helsinki Convention (UNECE 1992), the International Law Commission's 2008 Draft Articles on Transboundary Aquifers (ILC 2008), numerous regional and basin-specific agreements (Wolf 2002) and decisions by international courts.

Within the context of this development of IWL, the UN Watercourses Convention (UNWC) holds an important position. The Convention was negotiated on the basis of Draft Articles developed by the ILC and its final text, adopted at the UN General Assembly in 1997, is the result of ardent discussions between states and the recommendations of no less than five special rapporteurs. ${ }^{2}$ The UNWC was proposed as a response to the acknowledgment that a global legal instrument was needed to bolster cooperation between states over their shared water resources and mitigate the potential for conflict. It is also important to note that the UNWC was meant as a global treaty whose role was to support other watercourse treaties by acting as a template and filling the gaps where coverage was lacking (McCaffrey 1998).

Along with the UNECE Helsinki Convention (which will soon be open to accession by non-UNECE members (UNECE 2013)), the 1997 UNWC is the

1 See Wolf (2002) for a list of transboundary water-related agreements.

2 For details of the negotiation and adoption process see Salman (2007). 
only global treaty governing transboundary watercourses (McCaffrey 2008). As a framework convention, it is principle-driven rather than result-driven; it provides rules that can be tailored to the distinct circumstances of each international watercourse and gives liberty to watercourse states to take the actions that suit their needs and interests as required by the singularity of the situation (McCaffrey 2008). Both the Southern African Development Community (SADC) 2000 Revised Protocol on Shared Watercourses, and the 2009 Agreement on the Nile River Basin Cooperative Framework provide examples of instruments that have tailored the provisions of the 1997 UNWC to a regional and basinspecific context.

The UNWC, which is now widely recognised as the most authoritative source of international water law, is a pivotal document of IWL in a number of ways: it creates a strong framework for water governance arrangements (Rieu-Clarke and Hayward 2007) and a basic common ground that enhances predictability and encourages reciprocity (Rieu-Clarke and Lopez 2013); it codifies and clarifies existing norms and develops emerging principles of customary IWL; it constitutes a model that can guide the interpretation of other treaties and the negotiation and drafting of future ones (Rocha Loures et al. 2013); and, it has informed the judgments of international and regional courts (McCaffrey 2008).

The key aim of the Convention is to 'ensure the utilisation, development, conservation, management and protection of international watercourses and the promotion of the optimal and sustainable utilisation thereof' (UNWC 1997). The provisions of the Convention develop and consolidate fundamental principles of IWL:

1. Equitable and reasonable use and participation, stipulates that states reconcile any competing claims to an international watercouse on the basis of equity whilst protecting the sustainability of the system. Pursuant to the 1997 UNWC such claims should be reconciled based on all relevant factors and circumstances, and no use enjoys inherent priority (articles 5 and 6).

2. Obligation not to cause significant harm, which places states under a due diligence obligation to take all appropriate measures not to prevent signifcant harm to other watercourse states, unless it can be ascertained that such harm is both equitable and reasonable (Article 7).

3. Protection of ecosystem, whereby states are under an obligation, either individually or where appropriate jointly, to protect and preserve the ecosystems of an international watercourse (Article 20).

4. General obligation to cooperate, which requires that states cooperate on the basis of sovereignty, equality, territorial integrity, mutual benefit and good faith (Article 8). Such cooperation may lead to the adoption of watercourse agreements and joint institutions. 
5. Notificiation and consultation, whereby states must notify, exchange information and, if necessary, consult and negotiate with other watercourse states, on the possible effects of planned measures that may have a significant adverse effect upon other watercourse states (Part III).

6. Regular exchange of data and information, which obliges states to exchange data and information on the condition of the watercourse (Article 9).

7. Peaceful settlement of disputes, which requires states to settle their disputes in a peaceful manner via a range of mechanisms including negotiation, mediation, conciliation, third-party fact-finding, arbitration and adjudication (Article 33).

Despite the discernable role played by the UNWC in the development of IWL and its influence in many river basins of the world, the treaty itself is not yet officially in force. Fifteen years after an overwhelming majority of states voted in favour of the adoption of the Convention, it has received 31 instruments of ratification, four short of the 35 needed for its entry into force. A range of reasons have been suggested as to why the convention has been slow to enter into force. These include treaty congestion at the time of its adoption, lack of awareness relative to the content of the UNWC and low levels of understanding about its relevance, an absence of leadership in promoting ratification, and a number of highly vocal — but not necessarily widely representative - opponents who claim that there is no need for a global legal instrument (Rieu-Clarke and Hayward 2007; Dellapenna et al. 2013).

This situation has led a number of actors across the globe to campaign for the ratification of the Convention by raising awareness and understanding of the Convention's text and organising events to publicise the benefits that the UNWC'S entry into force would bring to water governance. These awarenessraising efforts have been assisted by 2013 being declared 'International Year of Water Cooperation' by the UN General Assembly. A series of events, programs, projects and activities were organised throughout the year to promote water cooperation, several of which addressed the role and relevance of the UNWC (Rieu-Clarke 2013).

The UNWC Global Initiative, launched in 2006 by the World Wildlife Fund for Nature (WWF), is one of the high-profile campaigns surrounding the UNWC. ${ }^{3}$ The Global Initiative has mobilised a range of actors including governments, international organisations and academics in an effort to raise awareness, build capacity, and support countries interested in ratifying the Convention. In order to deepen knowledge and understanding of the relevance of the Convention, the initiative has supported research related to the Convention in various regions, basins and countries, with a view to securing additional state ratifications and the instrument's eventual entry into force. 
A key output of the UNWC Global Initiative was the UNWC User's Guide (RieuClarke et al. 2012) developed by the Centre for Water, Law, Policy and Science under the auspices of UNESCO at the University of Dundee. This Guide is one of the major tools supporting the efforts towards the Convention's entry into force. It was conceived out of the recognition that increased awareness and enhanced accessibility are the key to the effective adoption and implementation of the UNWC. Indeed, the guide is intended to foster knowledge of the Convention among all relevant stakeholders, including policymakers, bodies responsible for transboundary water issues, and anyone wishing to gain insight into the Convention. It was designed to disseminate information about the UNWC and enhance understanding of the text and relevance of the Convention.

In addition to an overview of the legal architecture surrounding transboundary watercourses, recounting the history of the adoption process of the Convention and listing the opportunities and challenges of the UNWC's entry into effect, the guide offers a precise and thorough analysis of each of the Convention's provisions. It also provides examples of the benefits of the UNWC by demonstrating how it might be applied within a range of settings and scenarios, such as when determining whether a certain activity complies with the principle of equitable and reasonable utilisation, or in deciding whether or not a state should notify other states of a planned measure.

An Online User's Guide has been developed (Rieu-Clarke et al. 2013b) to complement the material provided by the user's guide. In addition to the Convention's text and the analysis provided by the user's guide, the website includes: exclusive media content, fact sheets and resources which feed into to the analysis of the role and relevance of the UNWC; case studies analysing the role and relevance of the UNWC in regions around the globe; and quizzes to test knowledge and understanding of the Convention.

The purpose of the online user's guide is to create a forum where documents can be freely accessed and the tools and analysis necessary to enhance knowledge and understanding of the UNWC are provided. The website also regularly posts news stories to allow readers to keep tabs on the latest developments in the world of international water law. One day, it is hoped that the title of one of those news stories will be: 'UNWC enters into force'.

The UNWC Online User's Guide can be accessed at: http://www. unwatercoursesconvention.com. You can also follow UNWC-related activities via twitter: @unwconline. The PDF version of the user's guide can be found at: http:// dl.dropboxusercontent.com/u/391260/UN\%20Watercourses \%20Convention \% 20 -\%20User\%27s\%20Guide.pdf.

The Centre for Water Law, Policy and Science under the auspices of UNESCO at University of Dundee was created in 2006. It is a world leader in its field 
and works to find new ways of effectively integrating law, policy and science to address water challenges of the twenty-first century. The centre undertakes a wide breadth of research and consultancy, recognising that if water law is to effectively implement integrated water-resource management and help the international community reach international development targets, it is essential to have legal frameworks to manage water rights and water quality and establish institutional mechanisms.

Ariel Litke is an intern at the Centre for Water Law, Policy and Science. He is currently pursuing a MA (research track) in Human Rights at the Paris School of International Affairs (PSIA) of Sciences Po, Paris. In 2012 he graduated top of his class at the University of Geneva, Switzerland, where he majored in international relations and was awarded the prize for best bachelor's thesis (law).

Alistair Rieu-Clarke is a Reader in International Law at the Centre for Water Law, Policy and Science at the University of Dundee. He holds an LLB in Scots law, an LLM in natural resources law and policy (with distinction), and a PhD in sustainable development, water and international law. Rieu-Clarke's research interests focus on assessing the effectiveness of transboundary watercourse treaty regimes and he has published extensively in the field of international law and water resources management.

\section{References}

Dellapenna, J.W., Rieu-Clarke, A. and Rocha Loures, F., 2013. 'Possible reasons slowing down the ratification process', in F. Rocha Loures and A. RieuClarke (eds), The UN Watercourses in Force: Strengthening international law for transboundary water management, Routledge, New York.

International Law Association (ILA), 1967. 'Helsinki rules on the uses of the waters of international rivers', Report of the 52nd Conference 484.

International Law Commission (ILC), 2008. 'Draft articles on the law of transboundary aquifers', Report on the work of its 60th Session, 63 U.N. GAOR Supplement No. 10, U.N. Doc. A/63/10.

McCaffrey, S., 1998. 'The UN Convention on the Law of Non-Navigational Uses of International Watercourses: prospects and pitfalls', in S.M.A. Salman and L.B. de Chazournes (eds), International Watercourses: Enhancing cooperation and managing conflict, World Bank, Washington, pp. 17-27.

— 2008. 'Convention on the Law of the Non-Navigational Uses of International Watercourses', United Nations. Available online at: http://legal.un.org/avl/ pdf/ha/clnuiw/clnuiw_e.pdf. 
- 2013. 'The progressive development of international water law', in F. Rocha Loures and A. Rieu-Clarke (eds.), The UN Watercourses in Force: Strengthening international law for transboundary water management, Routledge, New York.

Rieu-Clarke, A., 2013. 'Will 2013 be seen as the International Year of Water Cooperation?', Stockholm Water Front Magazine 2(July):12-13. Available at: http://www.siwi.org/wp-content/uploads/2013/07/WF-2-2013_Water-Law.pdf. and Hayward, K., 2007. 'Entry into force of the 1997 UN Watercourses Convention: barriers, benefits and prospects', Water21 9(6):12-16.

- Moynihan, R. and Magsig, B.O., 2012. UN Watercourses Convention - User's Guide, Centre for Water Law, Policy and Science, University of Dundee. Available at: http://dl.dropboxusercontent.com/u/391260/UN\%20 Watercourses \%20Convention \%20-\%20User \%27s\%20Guide.pdf. and Lopez, A., 2013. 'Why have states joined the UN Watercourses Convention?', in F. Rocha Loures and A. Rieu-Clarke (eds.), The UN Watercourses in Force: Strengthening international law for transboundary water management, Routledge, New York.

, Kinna, R. and Litke, A. 2013. UN Watercourses Convention: Online User's Guide, Centre for Water Law, Policy and Science, University of Dundee. Available at: http://www.unwatercoursesconvention.org/.

Rocha Loures, F., Rieu-Clarke, A., Dellapenna, J.W. and Lammers, J., 2013. 'The authority and function of the UN Watercourses Convention', in F. Rocha Loures and A. Rieu-Clarke (eds.), The UN Watercourses in Force: Strengthening international law for transboundary water management, Routledge, New York.

Salman, S.M.A., 2007. 'The United Nations Watercourses Convention ten years later: why has its entry into force proven difficult?, Water International 32(1):1-15.

United Nations Economic Commission for Europe (UNECE), 1992. 'UNECE Convention on the Protection and Use of Transboundary Watercourses and International Lakes' (adopted 17 March 1992, entered into force 6 October 1996), 1936 UNTS 269; 31 ILM 1312.

— 2013. 'UNECE water convention goes global'. Available at: http://www. unece.org/index.php?id=32154.

United Nations Watercourses Convention (UNWC), 1997. 'Preamble'. Available at: http://dl.dropboxusercontent.com/u/391260/UN\%20Watercourses\%20 Convention \%20-\%20User \%27s\%20Guide.pdf. 
Wolf, A.T., 2002. 'Atlas of international freshwater agreements'. Available at: http://www.transboundarywaters.orst.edu/publications/atlas/.

World Wildlife Fund for Nature (WWF), no date. 'UN Watercourses Convention'. Available at: http://wwf.panda.org/what_we_do/how_we_work/policy/ conventions/water_conventions/un_watercourses_convention/. 
This text taken from Global Water: Issues and Insights by R. Quentin Grafton, Paul Wyrwoll, Chris White and David Allendes, published May 2014 by ANU Press, The Australian National University, Canberra, Australia. 